\title{
Factors Affecting Employees Turnover Intentions in Khyber Pukhthunkhwa-Pakistan (A case Study of Habib Banks Limited, Peshawar Region)
}

\author{
Muhammad Fayaz*, Dr. Kashif Amin* and Dr.Naushad Khan ${ }^{* *}$ \\ *Department of Management Sciences, Qurtuba University of Science \& Information Technology Peshawar \\ **Institute of Development Studies, The University of Agriculture Peshawar
}

\begin{abstract}
The study was conducted in Peshawar region since 2018 and the major objective of the study was to see four different factors relation with the employees turnover intentions in Habib Bank Limitted Peshawar Region Pakistan. The total branches of Habib Bank Limited was 48 while only 14 branches on the basis of more employees were selected for the study. The total employees number in 14 branches was 215 while only 158 respondents were contacted for data collection because some respondents were not ready for filling the questionnaire. Descriptive statistics and regression analysis was used for data analysis. The constant value was 2.54 and was highly significant at .05 confidence level. Similarly the working environment coefficient was -.226 and was highly significant at .05 confidence level. Which shows that if the working environment increase one unit then 0.226 unit negative change will be occurred in the turnover intention of the employments of the HBL. The coefficient of Job Stress was 0.322 and was highly significant at .05 confidence level. It indicates that when one unit increase will be occurred in job stress then 0.322 unit change will be occurred in turnover intention of the HBL employees in the study area. The career growth coefficient was -.032 and was found non significant at .05 confidence level. The result shows that if one unit change will be occurred in career growth of HBL employees then 0.032 unit negative change will be occurred in the HBL Employee turnover intention. The compensation coefficient was -.123 and was significant at .05 confidence level. The result indicates that if one unit change will be occurred in compensation then .123 unit negative change will be occurred in the turnover intention of the employee of HBL. The F value of the model was 45.566 and the model was over all significant. The $\mathrm{R}^{2}$ value was 0.544 which shows how much the independent variables explain the model. On the basis of problems, following recommendations were suggested for its improvement:- Stressful environment for employees should be avoided and good working environment should be provided to the employees in the banks. Job stress should be reduced inside the bank. Chances for career growth should be facilitated to the HBL employees and compensation plan should be arranged for employee of the bank for reduction of turnover intention in the HBLPeshawar region. it is recommended for the future research worker to spread this study in other big cities of Pakistan to further clear the situation; Future research was also recommended to include other factors that might affect the turnover of the banking employees and in the long run which will improve also the outcome of the HBL.
\end{abstract}

Key words: $\quad$ Factors , Affecting Employees Turnover Intentions, Habib Bank Limited, Peshawar Region Khyber Pukhthunkhwa

DOI: $10.7176 / \mathrm{JESD} / 11-11-02$

Publication date:June 30th 2020

\section{INTRODUCTION}

Habib Bank Limited was established originally in 1941 when Mohammad Ali Jinnah requested to the administration of subcontinent to shift this bank operations into Pakistan, they shifted in 1947 and hence, HBL became first commercial bank of the country. Due to first bank of the country, HBL was progressing year by year and continued growth to present situation. In 1951, the bank opened its first ever international branch in Sri Lanka. After this the iconic HBL Plaza was completed in 1972. Moreover, in 1972 HBL celebrates their $25^{\text {th }}$ anniversary in Pakistan. Habib Bank was nationalized in 1974. In the banking industry, HBL became a trend setter by giving more loans to small and medium enterprises, farmers and traders. With the passage of time, the international operations of the bank were increasing and currently HBL is working in 25 different countries around the world. The Privatization Commission of Pakistan announced in 2003 that 51\% shares of HBL were transferred to Agha Khan Fund for Economic Development (AKFED) and invested 389 million US dollars. After such a huge investment, the management control was handed over to the AKFED in 2004. The government of Pakistan got 
control over their entire shares in 2015 and officially announced HBL as largest private bank of the country. According to annual report of 2016, HBL has more than 15000 employees working in all branches of Pakistan. The people working in banking and some time quit from the job and joined other industry or banks in the country and Turnover intention have been started in the banks employee. Turnover has two main categories. The first one is known as voluntary turnover, while the second one is known as involuntary turnover. In both the cases, organizations faces the cost of turnover. Diskienè, (2012) conducted a study and has argued that in both voluntary and involuntary turnover, the organizations have to suffer by bearing different costs including cost of training, hiring, recruiting, retaining, disruption of communication and social structures and loss of productivity during replacement search. Few of the researchers have found trust relationship with their employees. Therefore, trust is considered as an important variable in examining the turnover intention of employees. In a research conducted by Kuttessis, (2017), trust is defined as willingness of one party to be vulnerable to another party based on competency and reliability of the following party. If there is constant misunderstandings between the employee and the management, then the distrust between the employees would probably decrease the employment term and thus will lead to the intention of the employees to quit. The desire to leave the organization could be categorized in different categories like unavoidable or unpreventable turnover, undesirable turnover and desired turnover. The unpreventable turnover occurs mostly due to family issues, retirement or personal illness. Moreover, the desired turnover might be caused due to the inability of the employees and the undesirable turnover is a kind of turnover which is mainly caused due to inabilities from organization side like poor support, lack of supervision and role conflict etc. All these types of turnover affect the effectiveness of an organization, quality of product as well as customer service

Banking industry is one of key players in financial markets operations. It plays an important role in keeping a country's economy and massively contributes for GDP growth of the nation. Provision of good quality of services, high productivity, and gaining profits are among major goals of an industry including banks. A lot of money is spent by the organizations on training and orientation, preserving, and developing their job-related skills. Therefore, at all expenses, the administration is busy in making employees retention strategies. Although, there is no ordinary context for understanding the personnel turnover intention procedure as whole, a wide array of aspects have been initiate useful in initiating employee turnover intention. Turnover intentions are acknowledged by higher officials, and HR managers due to its multi-dimensional untoward effects, in banks (Anwarul \& Zaman, 2013). After the joining of banking industry by the private commercial banks, increased number of banks has created stiff market competition. The flourishing number of banks has also created a lot of employment opportunity to the nation, but it has also produced many staff turnovers intention in banks even if the bank has employed many staff retention strategies (Babalola et al., 2013). Therefore, keeping in view the advantages of banks to the economy and different retention strategies adopted by banks, this study examines the factors influencing employee turnover intention in Habib Bank Ltd. in its branches located in Peshawar. In the field of human resource management, employee's turnover intention is a major issue. Turnover intention could be defined as the own decision of an employee to quit the job in some near future time (Bentein, et al. 2002). In most of the countries the intention to quit by an employee gives many sleepless nights to the HR managers. In many countries it is believed that due to lack of manpower, the employees are getting into bad behaviors. There are many studies that examined the turnover intention of employees because it is a serious problem that is faced around the world. Despite enormous research 
Journal of Economics and Sustainable Development

ISSN 2222-1700 (Paper) ISSN 2222-2855 (Online)

work on turnover intention, this issue is not yet decreased. In many companies there are three sets of past experiences related to turnover intention i.e., demographic, controlled. Moreover, there is scarcity of research on factors on employees' turnover intention in specifically in Banking Sector, Peshawar and the huge detrimental impact of turnover intention on the banking sector is the main reasons for studying this topic. Seeing to its importance the present study was arranged in the study area. The study major objective was to investigate impact of work environment, Job Stress, career growth, compensation on employee turnover intention in the study area.

\section{METHODS AND MATERIALS}

The research methodology consist of four sections such as Universe of the study area, sample size and sampling procedure, data collection tool and data analysis techniques.

\section{Universe of the Study Area}

The total branches of Habib Bank limited in Peshawar were 48 while purposively 14 branches were selected for the study due to time and financial constraints. Population of the study includes all employees working in different sampled branches of Habib Bank Ltd. located in Peshawar region. The respondents were included all managerial staff, operational managers, credit officers and consultants of the sampled branches of Habib Bank Ltd. Total employees working in the sampled branched of HBL are 215, see detail in table 1.

Table 1 List of Sampled Branches of Habib Bank Limited in Peshawar Region

\begin{tabular}{|l|c|}
\hline Branch Name & No. of Employees \\
\hline Agriculture University, Shopping Centre Palosi, Peshawar & 11 \\
\hline HBL Arbab Road Branch & 19 \\
\hline Aurangzeb Ground, Rear Air Headquarter, Peshawar Cantt. & 12 \\
\hline Habib Bank Mathra Branch & 16 \\
\hline Bank Square. Peshawar (Ander Sher) & 18 \\
\hline HBL G.t. Road Branch & 16 \\
\hline Bilal Market, Hayatabad, Peshawar & 15 \\
\hline ChowkAbresham Gran, Peshawar City & 11 \\
\hline Nauthia, Sonheri Masjid Road, Peshawar Cantt. & 21 \\
\hline Gulbahar Colony No.2 & 18 \\
\hline Jamrood Road - University Campus & 13 \\
\hline HBL Peshawar Cantt. & 11 \\
\hline Police Line, Peshawar & 19 \\
\hline HBL TehkalBala, Peshawar & $\mathbf{2 1 5}$ \\
\hline Total & \\
\hline
\end{tabular}

Source: www.hbl.com.pk/gismap 


\section{Sample Size and Sampling Procedure}

Keeping in view the tough daily tasks of the banking staff, the judgmental sample technique is used because the sample size was accessible. The sampling procedure used was accessible sampling in which those employees were taken as respondents of the study who are free and willing to fill the questionnaire which make about 158 and comprises banks staff including managerial staff, operational managers, credit officers and other consultants working in different sampled branches of HBL, Peshawar. From total 215 employees 158 respondents filling the questionnaire which counted $74 \%$ of the total respondents 215 .

\section{Data Collection Tool}

The data collection process for this current study was done through primary data collection methods. The data was collected using pre-designed questionnaire and were distributed among the employees of the sampled HBL bank branches. The scale of instrument for this study was 5 point likert scale.

\section{Data Analysis}

Statistical package for social sciences (SPSS) was used as a tool of analysis for this current study in order to find the appropriate results for the regression analysis. Before regression analysis, reliability test, variance inflation factor test for multi-collinearity and heteroskedasticity test were applied to check the regression assumption.

\section{Theoretical Framework}

Theoretical model of the study is shown in the below figure.

\section{Independent Variables}

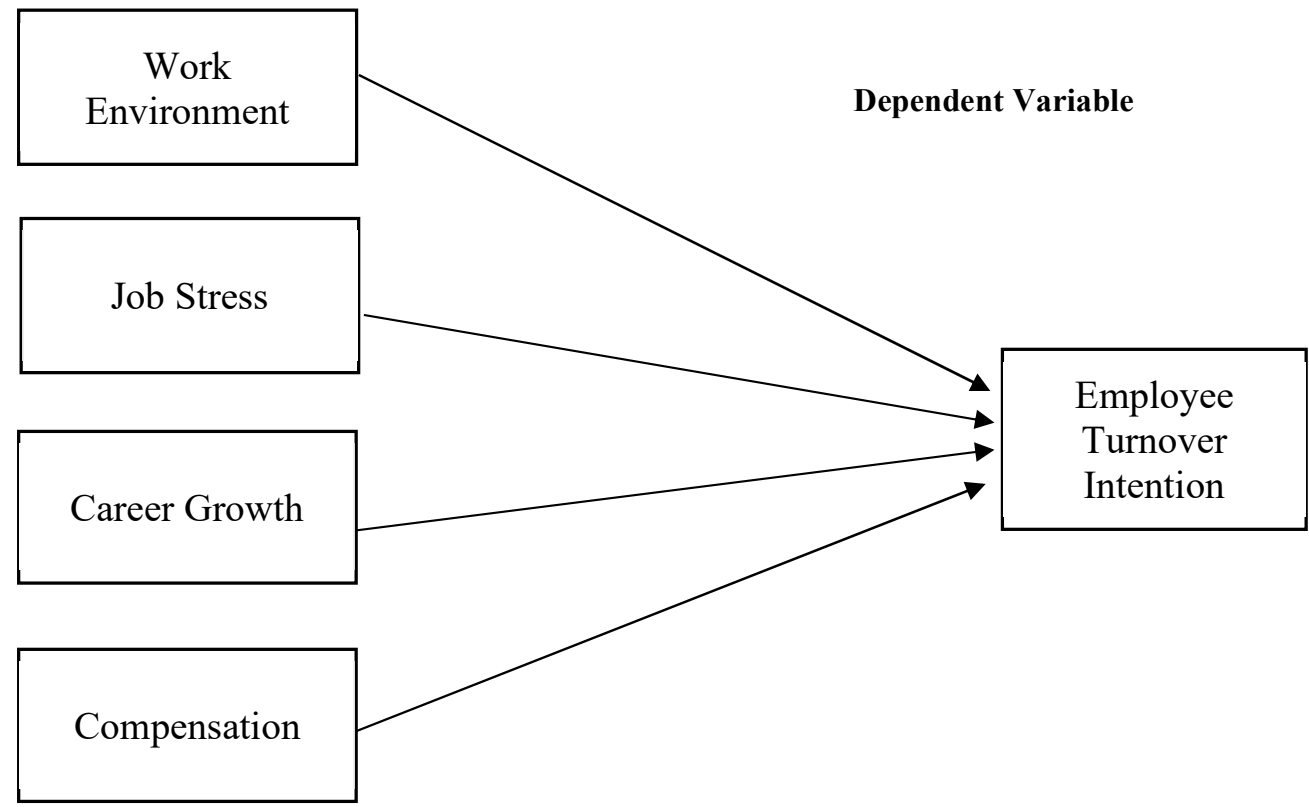




\section{Fig. 1: Theoretical Framework}

Above is the theoretical framework of the study. In this framework, the independent variables are work environment, job stress, career growth and compensation, while employee turnover intention is taken as dependent variable.

$\mathrm{Y}=\mathrm{a}+{ }_{\mathrm{b}} \mathrm{We}-{ }_{\mathrm{b} 1} \mathrm{Js}-{ }_{\mathrm{b} 2} \mathrm{Ca}-{ }_{\mathrm{b} 3} \mathrm{Co}$ Eq.1

$\mathrm{Y}=$ Turnover Intention of Employee, $\mathrm{a}=$ Constant, $\mathrm{We}=$ Work Environment, $\mathrm{J}_{\mathrm{s}}=\mathrm{Job}$ Stress, $\mathrm{Ca}=\mathrm{Career}$ Growth, $\mathrm{Co}=$ Compensation

\section{RESULTS AND DISCUSSION}

This section includes the results obtained after analyzing the data using SPSS. The analysis is divided into two different parts. In its first part the demographic statistics of the data is mentioned with the help of frequency tables and histogram. In the, heteroskedasticity, variance inflation factor test and regression analysis are mentioned. All these results are explained below in detail.

\section{Demographic Characteristics of the Respondents}

The demographical characteristics of the respondents are represented in the form of tables..

Table 2 Gender Composition of the Sampled Respondents' in the Study Area

\begin{tabular}{|l|c|c|}
\hline Gender & Frequency & Percentage \\
\hline Male & 88 & 55.70 \\
\hline Female & 70 & 44.30 \\
\hline Total & 158 & 100 \\
\hline
\end{tabular}

Field Survey 2018

Table 2 shows gender composition of the respondents. It is found from the table that in the total respondents about $88(55.7 \%)$ are male respondents, while $70(44.30 \%)$ of them were female respondents. The female number is less than the male in the banks of HBL Branches. Male and female gender has different role in the development of bank. The language of the females are very soft and they attract the people very easily which highly improve the reserve money of the bank while male language is very hard and attraction is less but the people of study area mostly not allow female to banks jobs because of this the number there in the bank is less.

Table 3 Age Wise Distribution of the Sampled Respondents in the Study Area

\begin{tabular}{|l|c|c|}
\hline Category of Age (Years) & Frequency & Percentage \\
\hline $20-25$ & 44 & 27.8 \\
\hline $26-30$ & 49 & 31.0 \\
\hline $31-35$ & 24 & 15.2 \\
\hline Above 36 & 41 & 25.9 \\
\hline Total & 158 & 100 \\
\hline
\end{tabular}

Table 3 depicts age wise distribution of the sampled respondents in the study area. It is found that about 
Journal of Economics and Sustainable Development ISSN 2222-1700 (Paper) ISSN 2222-2855 (Online)

$44(27.8 \%)$ of the total respondents were aging between $20-25$. It is further disclosed that about 49 (31.4\%) of the respondents were aging between26-30. Moreover, about 24 (15.2\%) of the respondents were aging between 31-35 and $41(25.9 \%)$ of the respondents were aging 36 and above. Majority people are in 26-30 age category followed by 20-25 age categories, while the lowest number is present in above 31-35 age category followed by above 36 age category. Age is very important factors because the people who age are more so they have great experiences and they play great role in the development of the bank while in those staff majority are ill which disturb their efficiency of the work which negatively affect the bank out come. Similarly whose age are less, their experience is less while they are more energetic for the work which push the outcome of the bank positively. So both categories have positive and negative effects.

Table 4 Education Level of the Sampled Respondents in the Study Area

\begin{tabular}{|l|c|c|}
\hline Education Level & Frequency & Percentage \\
\hline Bachalars & 37 & 23.4 \\
\hline Masters & 100 & 63.3 \\
\hline MS/M.Phil/Ph.D & 21 & 13.3 \\
\hline Total & 158 & 100 \\
\hline
\end{tabular}

Table 4 indicates educational background of the respondents. It is found that about 37 (23.4\%) of the total respondents were having bachelor's degree as their educational qualification. Moreover, about $100(63.3 \%)$ of them were master's degree holders and only 21 (13.3\%) of the respondents were having MS/M.Phil or Ph.D. The majority respondents have Master Degree which is followed by Bachelor degree while lowest respondents have MS/M.Phil/Ph.D degree which is followed by Bachelor Degree. Education level is the important factors which play great role in the development of bank outcome. They have more skill and very easily adapt the modern technology which is the demand of the present situation. They operate the computer very well and very easily know the techniques how to solve the banking financials crisis.

\section{Diagnostic Test of Regression Analysises}

Similarly for regression analysis different assumptions were checked and no issue was found. VIF test was used for multi Co linearity. Allison (1999) told that if its value falls less than 10, then no issue of co linearity is there in the data. Heteroskedasticity was checked with the help of white test. The current data Chi-square was $(22)=22.930257$, with $p$-value $=0.0614$, which indicates the acceptance of the null hypothesis and rejection of the alternative hypothesis. So, according to White's test result, there is no heteroskedasticity issue in the data. Normality was checked with the help of Shapiro -Wilk test and data was found normalmal.

Table 5

Coefficients of Different Variables with Turnover Intention of Sampled Respondents in the Study Area

\begin{tabular}{|c|c|c|c|c|c|c|}
\hline (Constant) & 2.540 & .255 & & 9.961 & .000 & $\begin{array}{l}\mathrm{R}=.737, \quad \mathrm{R}^{2}=.544 \\
\text { AdjustedR } \mathrm{R}^{2}=.532 \\
=\end{array}$ \\
\hline
\end{tabular}


Journal of Economics and Sustainable Development ISSN 2222-1700 (Paper) ISSN 2222-2855 (Online)

\begin{tabular}{|c|c|c|c|c|c|}
\hline Job Stress & .322 & .069 & .295 & 4.636 & .000 \\
\hline Career Growth & -.032 & .046 & -.046 & -.704 & .483 \\
\hline Compensation & -.123 & .059 & -.183 & -2.071 & .040 \\
\hline
\end{tabular}

Table 6, shows the coefficients of different variables with turnover intention of sampled respondents in the study area. According to table the coefficient value of relation between turnover intention of employee's and working environment is -0.226 . Since, the sign of this value is negative, therefore, the relationship between these two variables is negative. The negative relation further means that if there is made one unit increase in working environment, it will affect the employee turnover intention negatively by -0.226 units. Hence, working environment of the banks in Peshawar negatively affects the turnover intention of the employees. It further means that if the working environment is made better, the turnover intention of the employees will reduce. The t-value of this relationship is -4.184 with p-value of 0.004 , which means that there is significant relation of work environment with employee turnover intention. Thus, it is clear that working environment plays an important role in turnover intention of the employees in banks. If the employees are provided better working environment, they could be worked well and the outcome will be also well while if the working environment for banking employees is not good, then they might quit the job. Similarly Shamsuzzoh and Sumon, (2010) argued that working conditions of an organization are substandard or work organization lacks necessary facilities like adequate furniture, proper lighting, and other safety and health provision, then the employee will stay for long time in the organization. Another study indicated that instability of an organization has a huge negative impact on turnover intention of the employees(Babalola, et. al. 2013). Another researcher told that turnover is caused due to unhappiness of the employees from the work place (Shamsuzzoh and Sumon, 2010). The coefficient of Job Stress and Turnover intention of the employee was found 0.322 , which one unit increase in job stress, it will also increase the turnover intention of the employees at banks in Peshawar by 0.322 units positively. This further means that increase in job stress increases the turnover intention of the employees at banks in Peshawar. The below table indicated that pvalue is 0.000 , which also shows significant relationship between job stress and employee's turnover intention. Thus, the significant relation between these two variables leads to the acceptance of second alternative hypothesis. In the table the beta value of career growth and employee turnover intention is -.032 . The negative sign of the value indicates negative impact of one variable on another. Subsequently Khattak, et. al., (2010 and Firth, et al., 2004 told that job frustration and Job stress affect the turnover intention of the employee negatively of the employees and they try how to quit the organization and joined the job there where the job stress is nil and the environment is good. The coefficient of the career growth and turnover intention of the employee was -0.32 units. Which shows that when career growth increase one unit then 0.32 decrease will be occurred in the turnover intention of the employee. The $\mathrm{P}$ value in the below table is 0.000 which shows that result highly significant at .05 confidence interval. Thus, it is clear that career growth opportunities for employees working in banks is an important element while deciding about turnover because higher the career growth opportunities for the employees, lower will be their turnover intention. The coefficient value of compensation and employee turnover intention is -.123 which shows negative relationship of compensation with the turnover intention of the employee of the bank which shows that when 0.123 units increase in compensation then 0.123 negative change will occurred in the turnover intention of the employee. The $\mathrm{P}$ value is .04 which shows the result of the compensation and 
Journal of Economics and Sustainable Development

ISSN 2222-1700 (Paper) ISSN 2222-2855 (Online)

turnover intention of the employee of the bank is significant at .05 confidence interval level. Thus, it is clear that compensations has significant, but negative impact with turnover intention of the employees of HBL bank in Peshawar. Moreover, according to these results, if the employees are given sufficient compensations, they will tend to quit the decision of leaving the job.

In the table the $\mathrm{R}$ value is 0.737 , which means that the dependent and independent variables of the study have positive correlation. The next value in the table is R-square. This shows the coefficient of determination and means that how much of the change in dependent variable is caused by all independent variables of the study. It is normally considered as a percentage change in dependent variable due to independent variables of the study. Since, the value of R-square in the above table is 0.544 , which means that about $54.4 \%$ of the change in dependent variable (employee turnover intention) is caused by the independent variables. It is also found from this value that $45.6 \%$ of the change in employee turnover intention is caused by other factors that are not included in the study. Keeping in view the context of this study, it is found that employee turnover intention in banking sector are influenced by work environment, work stress, career growth and compensation. And their influence is about $54.5 \%$ of employee turnover intention. The modified version of R-square is known as Adjusted R-square. It is adjusted for predictors (independent variables) in an OLS regression model. The only difference among these two concepts is that adjusted R-square shows the percentage change in dependent variable because of the only independent variable that actually have impact on dependent variable, while in R-square the overall impact of every independent variable is shown on dependent variable. If we add another variable in the model, then value of adjusted R-square will only increase if the variable which is newly added is found meaningful for the model assumed. The value of adjusted R-square found for the current model is 0.532 . So many researchers have worked on this topic and the detail is given as. Turnover has two main categories. The first one is known as voluntary turnover, while the second one is known as involuntary turnover. In both the cases, organizations faces the cost of turnover. Diskiene, (2012) conducted a study and has argued that in both voluntary and involuntary turnover, the organizations have to suffer by bearing different costs including cost of training, hiring, recruiting, retaining, disruption of communication and social structures and loss of productivity during replacement search. Few of the researchers have found trust relationship with their employees. Therefore, trust is considered as an important variable in examining the turnover intention of employees. In a research conducted by Kuttessis, (2017), trust is defined as willingness of one party to be vulnerable to another party based on competency and reliability of the following party. If there is constant misunderstandings between the employee and the management, then the distrust between the employees would probably decrease the employment term and thus will lead to the intention of the employees to quit. The desire to leave the organization could be categorized in different categories like unavoidable or unpreventable turnover, undesirable turnover and desired turnover. The unpreventable turnover occurs mostly due to family issues, retirement or personal illness. Moreover, the desired turnover might be caused due to the inability of the employee and the undesirable turnover is a kind of turnover which is mainly caused due to inabilities from organization side like poor support, lack of supervision and role conflict etc. All these types of turnover affect the effectiveness of an organization, quality of product as well as customer service. Ongori, 2007; Rehman, 2012; Thamas 2012; Chipunza, 2009; Achoui and Mansour, 2007; Nadeem, et al 2011; Morrell, et al 2001; Dess and Shaw, 2001;Allen, 2000, these mentioned researchers told that there are so many factors which affect the turnover intention of the employees in different organization. They focuses that good working environment, good 
compensation to Employers and less stress to employers and skill development of the employers improve the function of the work and decrease the chances of turnover intention in the employees which latter on push the output of the industry well while there the situation in Peshawar region. Influential people and politician get the jobs for their relative through favoritism and nepotism which latter on make the bank defaulter and not solve the problems according to their objectives. In this research only four factors have been link with the turnover intentions of the employees while other sectors have been ignored in this study while I suggested to include to factors which are untouched in this research .

\section{Conclusion and Recommendations}

This study concluded that different variables as factors that may influence turnover intention of the sampled employees. These variables include work environment, job stress, career growth opportunities and compensations. All these factors are examined in this study to find out their impact on employee's turnover intention. The constant value was 2.54 and was highly significant at .05 confidence level. Similarly the working environment coefficient was -.226 and was highly significant at .05 confidence level. Which shows that if the working environment increase one unit then 0.226 unit negative change will be occurred in the turnover intention of the employments of the HBL. The coefficient of Job Stress was 0.322 and was highly significant at .05 confidence level. It indicates that when one unit increase will be occurred in job stress then 0.322 unit change will be occurred in turnover intention of the HBL employees in the study area. The career growth coefficient was -.032 and was found non significant at .05 confidence level. The result shows that if one unit change will be occurred in career growth of HBL employees then 0.032 unit negative change will be occurred in the HBL Employee turnover intention. The compensation coefficient was -.123 and was significant at .05 confidence level. The result indicates that if one unit change will be occurred in compensation then .123 unit negative change will be occurred in the turnover intention of the employee of HBL. The F value of the model was 45.566 and the model was over all significant. The $\mathrm{R}^{2}$ value was 0.544 which shows how much the independent variables explain the model. On the basis of problems, following recommendations were suggested for its improvement:- Stressful environment for employees should be avoided and good working environment should be provided to the employees in the banks. Job stress should be reduced inside the bank. Chances for career growth should be facilitated to the HBL employees and compensation plan should be arranged for employee of the bank for reduction of turnover intention in the HBLPeshawar region. it is recommended for the future research worker to spread this study in other big cities of Pakistan to further clear the situation; Future research was also recommended to include other factors that might affect the turnover of the banking employees and in the long run which will improve also the outcome of the HBL.As the sample size of this study is limited to 158 employees only, therefore future research work should consider larger sample size to examine these results more clearly; Finally, the researchers are recommended to conduct a comparative study of Islamic and conventional banks to find out factors influencing turnover intention of employees.

\section{ACKNOWLEDGEMENT}

I want to express thanks from the core of my heart to my research supervisor. Dr. Kashif Amin for his 
guidance, suggestion and discussion throughout my research work. Without his guidance, kind attention and encouragement this work would have not been in present form. At the end I present a special thanks to my parents and other family members whose prays, support and motivation enabled me to reach this level.

\section{AUTHORS CONTRIBUTIONS}

Muhammad Fayaz created the Idea for his M.Phil thesis and collected the data from the field and wrote his thesis while Dr.Kashif Amin Supervised the whole thesis and helped in writing of the report. Similarly Dr.Naushad Khan gave structure to the paper and corresponded with the Journal editor and reply to Journal reviewer questions and give answer in time and polish the paper. 


\section{LITERATURE CITED}

1. Anwarul, I., Zaman, M. (2013). Job satisfaction \& Banker turnover: A case study on Bangladesh commerce Bank limited. European canter for research training and development UK. Vol 1 no 4 pp 114.

2. Aga Khan Fund for Economic Development (2004).

3. Babalola, O. Gbadegesin, A. Patience, E. (2013). The place of job stress in labour turnover of the banking sector in the Nigerian economy. International journal of business and management inventions. Vol2 no 1 pp, 93-99.

4. Bentein, K., Stinghlamber, F. and Vandenberghe, C. (2002). Organization-, supervisor-, and workgroupdirected commitments and citizenship behaviours: A comparison of models. European Journal of Work and Organizational Psychology, Vol. 11 No. 3, pp. 341-62.

5. Curtis, S., and Wright, D. (2001).Retaining employees - the fast track to commitment. Management Research News, 24 (8/9), 59-64.

6. Dess, G. D., and Shaw, J. D. (2001). Voluntary turnover, social capital and organizational performance. Academy of Management Review, 26 (3), 446-456.

7. Diskienė D, Goštautas V (2012). The fit of individual and organizational values in Business Company. Managerial Challenge at Contemporary Society 3: 130-134.

8. Firth, L., David, J., Mellor. Kathleen, A. Moore, C. (2007). How can managers reduce employee intention to quit? J. Manage. Psychol. 19 (2): 170-187. [10]. Price, J.L (1977). The study of turnover, 1st edition, Iowa state university press, IA pp10-25.

9. Gabriel, D. and Thomas, K. (2012). Labour turnover and its impact on performance of Banks in Ghana. European Journal of Business and Management.Vol. 4, No.7.

10. Khattak, et. al. (2010). Occupational stress and burnout in Pakistan's banking Sector. African Journal of Business Management Vol. 5(3), pp. 810-817, 4 February, 2011

11. Kuttessis, J. (2017). Job attitudes and the employee engagement and retention functional area, creating a supportive workplace, SHRM.

12. Lema, D. G. P., and Durendez, A. (2007). Managerial behavior of small and medium-sized family businesses: an empirical study. Journal of Entrepreneurial Behavior\& Research, 13 (3), 151-172.

13. Morrell, K., Loan-Clarke, J., and Wilkinson, A. J. (2001). Unweaving leaving: The use of models in the management of employee turnover. International Journal of Management Reviews, 3 (3), 21 9-244.

14. Nadeem, S., Aysha, M., Yasir, T., Hussain T. (2011). Losing your best talent: employee retention the dilemma of textile industry a case of textile sector. Inter-displinary journal of contemporary research business, December 2011, vol3.

15. Ongori, H. (2007). A review of the literature on employee turnover. African Journal of Business Management pp. 049-054. 
16. Pendulwa, G. (2011). Organizational factors impacting on employee retention, unpublished Master Thesis, Nelson Mandela Metropolitan University.

17. Rehman, S. (2012). Employee turnover and retention strategies: empirical studies of public sector organizations of Pakistan. Global Journal of Management and Business Research.Vol.12.

18. Samuel, M. and Chipunza, C. (2009). Employee retention and turnover: Using motivational variables as a panacea. African Journal of Business Management Vol.3 (8), pp. 410-415.

19. Shamsuzzoha, and Shumon, (2010). Employee Turnover-a Study of its Causes and Effects to Different Industries in Bangladesh. International Journal of Humanities and Social Science [Special Issue - July 2012].

20. www.hbl.com.pk/gismap 